\title{
Going Micro: Emerging and Future Peacekeeping Research
}

\author{
SÉVERINE AUTESSERRE
}

In the past 15 years, scholars have started studying the local and micro-level dimensions of peacekeeping. They have investigated the nature and effectiveness of bottom-up peacebuilding, assessed the local versus national impacts of peacekeeping interventions and studied the decentralized actions of international peacebuilders on the ground. This commentary shows that, despite the approach's limitations, delving into these three topics opens up fruitful areas for further research, in particular analysing micro-to-macro linkages, evaluating peacekeeping's subnational impacts across cases, explaining peacebuilding successes and understanding the causes of peace itself.

Studies of local and micro-level dynamics are relatively new in peacekeeping research. With few exceptions, up to the early 2000s, researchers focused on the national and international dimensions of peace efforts. This macro-level approach is still dominant today, to such a point that, in most analyses, 'local' means 'national'. In the past 15 years, however, a new focus on subnational dimensions has emerged. The resulting body of literature is very diverse - in terms of methodology, epistemology and substantive areas of concern. But the authors in this movement share a commitment to look at peacekeeping processes beyond international, national or capital-based dynamics.

Three themes motivate most of the research in this milieu. First is an attention to bottom-up peacekeeping and peacebuilding, whether by local populations or by international interveners. Second is an interest in the local effects of intervention, and the reasons why peacebuilding outcomes may differ at the micro- and macro-levels. Third is a consideration of the decentralized actions of international peacebuilders on the ground, focusing on the foreigners' diverse cultures and the everyday dimensions of their work. This article will discuss each of these themes in turn, emphasizing the main contributions that the authors have made to the broader research on peacekeeping, flagging the potential pitfalls and limitations, and identifying avenues for further research. ${ }^{1}$

Throughout, this essay uses a broad definition of peacekeeping, which reflects the definition prevalent in the literature under consideration. As explained in the introduction to this series of commentaries, a large majority of authors have moved away from the traditional, military-oriented definition of peacekeeping as peace operations conducted by the United Nations, specific states or other international organizations. Most researchers now include in their analyses a wider range of actors and activities, including non-governmental organizations, 
civil society groups and diplomats, as well as peacemaking and peacebuilding initiatives. As the rest of this essay illustrates, analysing these broader efforts is indispensable to grasp the bottom-up, local and micro-level dynamics of peacekeeping.

\section{Bottom-Up Peacekeeping and Peacebuilding}

The research on bottom-up peacekeeping emerged from a rejection of two assumptions prevalent in the literature: that micro-level conflict dynamics mirror those on the macro level, and that peace achieved on the national and international stages will automatically trickle down to the local spheres. ${ }^{2}$ Instead, Stathis Kalyvas, his students and his colleagues have demonstrated that local and subnational conflicts often motivate large parts of civil war violence. ${ }^{3}$ As a result, the intensity of violence regularly varies within the same country, and so do peacekeeping outcomes. ${ }^{4}$

This observation has inspired an evolution in the research on international peacekeeping. Various scholars have investigated the work that international actors do - or fail to do - to assuage local tensions and the reasons why attention to local rather than national conflicts remains so rare. ${ }^{5}$ There is also an emerging body of literature on how international actors can contribute to bottom-up peacebuilding, and the benefits, dilemmas and pitfalls involved in doing so. ${ }^{6}$ In addition, numerous researchers have studied peacekeeping and peacebuilding initiatives undertaken by local communities in the aftermath of conflict. ${ }^{7}$

These authors often draw the conclusion that only a combination of bottomup and top-down efforts can build a sustainable peace. ${ }^{8}$ This suggests a potential pitfall: studying local and bottom-up dynamics in isolation from their broader contexts. At the same time, it highlights an important area for further research: systematic analyses of the interactions between bottom-up and top-down peacekeeping are necessary to understand better how, why and under what conditions bottom-up efforts contribute to macro-level peace, and how top-down initiatives can boost or undermine the bottom-up efforts.

\section{Local Dimensions of International Interventions}

Authors whose research is oriented to the local and micro level point to another major issue with the existing literature: The dominant approach focuses on country-level (or mission-level) analyses, yet the subnational impacts of international efforts are often distinct from these macro, aggregated outcomes. It is therefore crucial to study the local dimensions of international interventions, in particular the actual impact of peacekeeping efforts on the ground and the responses of local populations.

\section{Local Impacts}

The overall findings of the local impact analyses are disheartening. Admittedly, natural experiments demonstrate that external intervention can help promote reconciliation. ${ }^{9}$ However, ethnographic studies show that international efforts 
are regularly counterproductive. Among other perverse effects, foreign peace interventions have increased the number and severity of human rights violations, ${ }^{10}$ hampered democracy, ${ }^{11}$ amplified gender disparities and sexual abuse, ${ }^{12}$ disrupted local economies ${ }^{13}$ and fuelled violence. ${ }^{14}$ Quantitative analyses are similarly pessimistic: despite some positive outcomes, peacekeeping deployment at the municipal level does not reduce subsequent violence, nor does it promote security or help restore local authority. ${ }^{15}$ Likewise, disarmament, demobilization and reintegration programmes and community-driven reconstruction projects regularly fail to reach many of their intended goals. ${ }^{16}$

Thus far, this research has only focused on a few cases of intervention. Additional studies are necessary, on many other cases, to assess the generalizability of these findings. When undertaking this research, authors should keep in mind three potential pitfalls, which Stathis Kalyvas identified when he reviewed the emerging literature on bottom-up dynamics of violence, and which similarly mar many of the studies on the local impacts of international interventions. There is a widespread tendency to exclude 'those macro processes that cannot be analyzed at the micro level', a 'pronounced lack of clarity on scope conditions' and a 'tendency, sometimes, toward reckless extrapolation from the micro to the macro level'. ${ }^{17}$ These shortcomings are particularly common in quantitative and experimental research designs, suggesting a need for mixed methods approaches that incorporate qualitative research to enhance the findings of the growing quantitative and lab-in-the-field literature.

Another important drawback of the quantitative and lab-in-the-field experiments is that they tend to equate micro-level factors with individuals' behaviour and attitudes, excluding potentially important variables such as local contexts and community dynamics. ${ }^{18}$ This is misleading because peaceful individuals do not necessarily make peaceful societies. ${ }^{19}$

\section{Local Responses}

The research on relationships between international interveners and host populations - just like the micro-level studies of international peacebuilders mentioned in the next section - helps explain many of the disappointing peacekeeping outcomes on the ground. Oliver Richmond and other scholars have demonstrated the contrast between the foreign interveners' conceptions of violence, peace, peacekeeping and peacebuilding and those of host populations. ${ }^{20}$ There is also a significant body of work on 'local ownership': what it is, why it is essential for successful peacebuilding, how it can be achieved and why it still eludes most international efforts. ${ }^{21}$

A relative consensus has emerged among these authors. Foreign interveners use a standard, universal conflict-management technique that overlooks the local specificities of the host communities. ${ }^{22}$ As a result, peacekeepers often employ unproductive approaches, become unpopular and, at times, end up in conflict with local populations or armed groups. In response, local authorities and populations regularly contest, adapt, transform or reject international programmes. ${ }^{23}$ 
This research faces two potential shortcomings. The first is the romanticization of 'local, indigenous, customary, and traditional approaches to peacebuilding. ${ }^{24}$ Several authors emphasize that such practices are often exclusionary, oppressive, authoritarian or discriminatory. ${ }^{25}$ The challenge for the analyst is to acknowledge the importance of bottom-up dynamics without idealizing them, and for the practitioner it is to build on local practices while avoiding their most unsavoury aspects. The second pitfall is treating 'the local' as a unified phenomenon. Residents of a host country, or a given village, do not form a homogenous community, and there is no such thing as one local viewpoint. Instead, any local population includes a multitude of political, economic, social and religious groups, which each has its own goals, beliefs, customs and attitudes. ${ }^{26}$ As a result, 'the local' is always highly fragmented. ${ }^{27}$

\section{Micro-Level Studies of International Peacebuilders}

The research on local and micro-level dynamics has made a third major contribution to the literature on peacekeeping. It has shifted the empirical focus from macro-level foreign policy - such as resources, vested interests, liberal values and the politics of United Nations mandates - to what international interveners actually do in the field. ${ }^{28}$

Most analyses of international peacekeepers on the ground demonstrate that their national, organizational, professional and gender cultures orient the choice of specific intervention strategies and affect their relationships with local populations. ${ }^{29} \mathrm{~A}$ more recent line of research emphasizes the importance of studying the foreign interveners' everyday lives and work in accounting for the characteristics and effectiveness of development and humanitarian programmes, ${ }^{30}$ democratization initiatives, ${ }^{31}$ securitization efforts ${ }^{32}$ and peacebuilding projects. ${ }^{33}$ This research on the everyday adds to the growing body of memoirs by former peacekeepers and peacebuilders deployed on the ground ${ }^{34}$ - some of which make a conscious effort to draw broader lessons for peacekeeping practice. ${ }^{35}$

All of the existing research on this topic is ethnographic and qualitative. As such, it presents little statistical evidence linking daily practice to peacebuilding outcomes. The work also tends to be very site specific. Thus, for many, it can appear anecdotal, overly personal or not rigorous enough, and lacking generalizability. All of the authors also come from anthropological or interpretive traditions, making it more difficult for the findings to travel to mainstream positivist research in political science and international relations. Quantitative and experimental inquiries could help to overcome these limitations by evaluating the strength and exportability of the qualitative findings.

\section{Ways Ahead}

Contributing to an emerging body of research presents both serious challenges and enticing opportunities. On the one hand, the authors face many pitfalls, which we are just starting to identify (and the most important of which are discussed above). On the other hand, each of the studies mentioned in this essay 
fills major gaps in our understanding of peacekeeping. While certain topics (notably the cultures and impacts of military peacekeepers) and cases (in particular Liberia and Bosnia-Herzegovina) have now been extensively examined, numerous other issues and countries remain under-investigated. In fact, many analyses of bottom-up peacekeeping, local impacts of non-military intervention and everyday dimensions of international peacebuilding on the ground are explicitly exploratory. The authors emphasize that their publications constitute first steps in opening what they hope will be new lines of inquiry, and that further research on their topics is crucial.

This commentary has offered several suggestions so that further research can avoid the shortcomings of previous analyses. The next studies of bottom-up peacekeeping should carefully unpack the interactions between micro-level and macro-level dynamics and examine the mechanisms through which bottom-up initiatives can (or cannot) contribute to national and international peace. Future examinations of local impacts should use qualitative inquiries to complement the findings of quantitative and experimental approaches, and consider multiple local-level factors besides individuals (such as grassroots institutions, community dynamics or degrees of rebel control). Moving forward, inquiries on local responses should better reflect the fragmentation of 'the local' and the potential unsavoury aspects of customary and traditional practices. Finally, future micro-level investigations of international peacebuilders on the ground would be strengthened through complementary quantitative or experimental approaches.

The overall literature on micro-level and local orientations presents three other important limitations, which suggests three more fruitful avenues for further investigation. To start, virtually all of the texts mentioned in this commentary focus on one specific subnational area or on various local places within one country. The resulting publications are convincing and insightful, but they have little potential for generalization. Comparative analyses across countries would help qualitative studies become more broadly applicable, as would databases gathering micro-level information across all conflict zones for quantitative investigations. ${ }^{36}$

In addition, thus far, micro-level studies of international interveners, as well as investigations on the local dimensions of intervention, have overwhelmingly focused on failure. This mirrors the broader research on peacekeeping, which, as Page Fortna and Lise Morje Howard have demonstrated, largely concentrates on problematic cases, ignoring successful experiences. ${ }^{37}$ However, as Fortna and Howard note, the obstacles to peacekeeping and peacebuilding are such that the most puzzling question is not why international efforts fail but rather why they sometimes succeed. A focus on instances where interventions have achieved either negative or positive peace, as perceived by both interveners and host populations, would greatly contribute to our understanding of local and micro-level dynamics. Three recent publications have proved particularly insightful and could provide inspiration for future research. The first two have conducted paired in-depth comparisons of two Bosnian cities that present similar characteristics, except that one is violent and the other surprisingly peaceful, in order to 
identify factors that explain peacebuilding success. ${ }^{38}$ The last study presents a thorough evaluation of intervention efforts in Aceh (Indonesia) in 2005 and 2006 to identify the 'key practical attributes' shared by the international agencies that did usefully contribute to the peace process. ${ }^{39}$

A last, related area of fruitful inquiry would be to focus on peace itself. Most studies assume that the causes of peace are the opposite of the causes of war. Yet, this is not necessarily true. Comparative anthropological research on peaceful societies around the world shows that elements such as avoidance of alcohol consumption and child-rearing practices that emphasize self-control - elements whose absence has never been identified as the cause of organized violence seem, in fact, to promote peace. ${ }^{40}$ This suggests the importance of delving into questions like: what are the sources of peace? A potential way to inquire into this topic would be to investigate why certain places (such as the province of Maniema in Congo) experience surprisingly little violence despite exhibiting all the characteristics that, according to existing research, exacerbate conflict.

All of this further research can have enormous policy implications. Since I started working on international peacebuilding 15 years ago, I have heard a constant refrain: policy-makers and practitioners continually deplore that while they know many of the standard peacebuilding models, templates and techniques that they use are ineffective, they nevertheless have to keep using these models and techniques because no one has yet offered a convincing alternative. The suggestions for future inquiry presented in this series of commentaries will hopefully contribute to building the credible alternatives that are so sorely needed, and studies of local, micro-level and bottom-up dynamics can play a key role in this process.

\section{ACKNOWLEDGEMENTS}

Thanks to Alexandra Russo and Stephanie Schwartz for their excellent research assistance, and to Paul F. Diehl for his very helpful feedback on a draft version of this article.

\section{ABOUT THE AUTHOR}

Séverine Autesserre is an Assistant Professor of Political Science, specializing in international relations, at Barnard College, Columbia University (USA). She works on civil wars, peacebuilding, peacekeeping, humanitarian aid and African politics. She is the author of The Trouble with the Congo: Local Violence and the Failure of International Peacebuilding (Cambridge, 2010) and Peaceland: Conflict Resolution and the Everyday Politics of International Intervention (Cambridge, 2014).

\section{NOTES}

1. This commentary builds on, refines and expands analyses developed in Séverine Autesserre, 'Construire la Paix: Conceptions Collectives de son Établissement, de son Maintien, et de sa Consolidation', Critique Internationale, Vol.51, 2011, pp.153-67; and Séverine Autesserre, Peaceland: Conflict Resolution and the Everyday Politics of International Intervention, New York: Cambridge University Press, 2014, introduction, ch.1 and conclusion.

2. For critical discussions of these assumptions see, for instance, Séverine Autesserre, The Trouble with the Congo: Local Violence and the Failure of International Peacebuilding, New York: 
Cambridge University Press, 2010, ch.2; and Carrie Manning, 'Local Level Challenges to Post-Conflict Peacebuilding', International Peacekeeping, Vol.10, No.3, 2003, pp.25-43.

3. Stathis N. Kalyvas, The Logic of Violence in Civil War, New York: Cambridge University Press, 2006. For examples of subsequent studies, see the various contributions to Patricia Justino, Tilman Brück and Philip Verwimp (eds), A Micro-Level Perspective on the Dynamics of Conflict, Violence, and Development, Oxford: Oxford University Press, 2013.

4. Stefano Costalli, 'Does Peacekeeping Work? A Disaggregated Analysis of Deployment and Violence Reduction in the Bosnian War', British Journal of Political Science, Vol.44, No.2, 2014, pp.357-80; and Eric Mvukiyehe and Cyrus Samii, 'The Subtle Effects of Peacekeeping: Evidence from Liberia', paper presented at the annual meeting of the American Political Science Association, Washington, DC, 3-5 September 2010, p.3.

5. For instance, Autesserre (see n.2 above); and Ken Menkhaus, 'International Peacebuilding and the Dynamics of Local and National Reconciliation in Somalia', International Peacekeeping, Vol.3, No.1, 1996, pp.42-67.

6. Representative examples include Kate McGuinness, Local First: Development for the TwentyFirst Century, London: Peace Direct, 2012; and Craig Zelizer and Robert A. Rubinstein, Building Peace: Practical Reflections from the Field, Sterling, VA: Kumarian Press, 2009.

7. Among many others: Kimberly Susan Theidon, Intimate Enemies: Violence and Reconciliation in Peru, Philadelphia: University of Pennsylvania Press, 2013; John Paul Lederach and Angela Jill Lederach, When Blood and Bones Cry Out: Journeys through the Soundscape of Healing and Reconciliation, New York: Oxford University Press, 2010; and the special issue of Peace Review on zones of peace (Vol.9, No.2, 1997).

8. Also John Paul Lederach, Building Peace: Sustainable Reconciliation in Divided Societies, Washington, DC: United States Institute of Peace Press, 1997.

9. For instance, Christopher Blattman, Alexandra Hartman and Robert Blair, 'How to Promote Order and Property Rights under Weak Rule of Law? An Experiment in Changing Dispute Resolution Behavior through Community Education', American Political Science Review, Vol.108, No.1, 2014, pp.100-20; James Fearon, Macartan Humphreys and Jeremy M. Weinstein, 'Democratic Institutions and Collective Action Capacity: Results from a Field Experiment in Post-Conflict Liberia', Working Paper, Stanford University and Columbia University, 2011 (at: www.columbia.edu/ mh2245/papers1/FHW_2012.pdf); and Elizabeth Levy Paluk and Donald P. Green, 'Deference, Dissent, and Dispute Resolution: An Experimental Intervention Using Mass Media to Change Norms and Behavior in Rwanda', American Political Science Review, Vol.103, No.4, 2009, pp.622-44.

10. Adam Branch, Displacing Human Rights: War and Intervention in Northern Uganda, New York: Oxford University Press, 2011.

11. Harri Englund, Prisoners of Freedom: Human Rights and the African Poor, Berkeley: University of California Press, 2006; and John Heathershaw, Post-Conflict Tajikistan: The Politics of Peacebuilding and the Emergence of Legitimate Order, London: Routledge, 2009.

12. Gabrielle Simm, Sex in Peace Operations, London: Cambridge University Press, 2013.

13. See notably Morten Bøås and Kathleen Jennings, Peacekeeping and the City: The Peacekeeping Economy in Liberia, DR Congo, and South Sudan, Norway: FAFO and NUPI, forthcoming.

14. Among others: Séverine Autesserre, 'Dangerous Tales: Dominant Narratives on the Congo and their Unintended Consequences', African Affairs, Vol.111, No. 443, 2012, pp.202-22; and Mike Martin, An Intimate War: An Oral History of the Helmand Conflict, 1978-2012, London: Hurst, 2014.

15. For instance, Costalli (see n.4 above); and Mvukiyehe and Samii (see n.4 above).

16. Among others: Michael Gilligan, Eric Mvukiyehe and Cyrus Samii, 'Reintegrating Rebels into Civilian Life: Quasi-Experimental Evidence from Burundi', Journal of Conflict Resolution, Vol.57, No.4, 2012, pp.598-626; Macartan Humphreys, Raul Sanchez de la Sierra and Peter van der Windt, 'Social and Economic Impacts of Tuungane: Final Report on the Effects of a Community Driven Reconstruction Program in Eastern Democratic Republic of Congo', Final Report, Columbia University, 2012 (at: http://cu-csds.org/wp-content/uploads/2012/06/20120622FINAL-REPORT.pdf); and Macartan Humphreys and Jeremy M. Weinstein, 'Demobilization and Reintegration', Journal of Conflict Resolution, Vol.51, No.4, 2007, pp.531-67.

17. Stathis Kalyvas, 'Promises and Pitfalls of an Emerging Research Program: The Microdynamics of Civil War', in Stathis Kalyvas, Ian Shapiro and Tarek Masoud (eds), Order, Conflict, and Violence, New York: Cambridge University Press, 2008, p.398.

18. Thanks to Stephanie Schwartz for flagging this point.

19. Sandrine Lefranc, 'A Critique of "Bottom-Up" Peacebuilding: Do Peaceful Individuals Make Peaceful Societies?', in Bruno Charbonneau and Geneviève Parent (eds), Peacebuilding, 
Memory and Reconciliation: Bridging Top-Down and Bottom-Up Approaches, New York: Routledge, 2013, pp.34-52.

20. Oliver Richmond, The Transformation of Peace, New York: Palgrave Macmillan, 2005. Other rrepresentative publications include Tanja Hohe, 'Clash of Paradigms: International Administration and Local Political Legitimacy in East Timor', Contemporary Southeast Asia, Vol.24, No.3, 2002, pp.569-89; and Gearoid Millar, An Ethnographic Approach to Peacebuilding: Understanding Local Experiences in Transitional States, London: Routledge, 2014.

21. See, for instance, Timothy Donais, Peacebuilding and Local Ownership: Post-Conflict Consensus-Building, Oxon: Routledge, 2012; and Mary Martin and Stephanie Moser, Exiting Conflict, Owning the Peace: Local Ownership and Peacebuilding Relationships in the Cases of Bosnia and Kosovo, London: London School of Economics - Friedrich Ebert Stiftung, 2012.

22. Among many others: Roger Mac Ginty, 'Indigenous Peace-Making versus the Liberal Peace', Cooperation and Conflict, Vol.43, No.2, 2008, pp.139-63; and Oliver Richmond and Audra Mitchell, Hybrid Forms of Peace: From Everyday Agency to Post-Liberalism, New York: Palgrave, 2011.

23. For example, Autesserre, Peaceland (see n.1 above), notably ch.3; Roger Mac Ginty, International Peacebuilding and Local Resistance: Hybrid Forms of Peace, London: Palgrave Macmillan, 2011; and Richmond and Mitchell (see n.22 above).

24. Mac Ginty (see n.23 above), p.2; Oliver Richmond, A Post-Liberal Peace, London: Routledge, 2011, part 1; Christoph Daniel Schaefer, 'Local Practices and Normative Frameworks in Peacebuilding', International Peacekeeping, Vol.17, No.4, 2010, pp.505-6; and Claudia Simons and Franzisca Zanker, 'Questioning the Local in Peacebuilding', Paper Presented at the Conference "New Frontiers of Peacebuilding”, Manchester, 13-14 September 2012 (at: www. spp1448.de/fileadmin/media/projects/Power_Sharing/SimonsZanker_Questioning_the_Local_in_ Peacebuilding.pdf. Please note that I have obtained the author's authorization to cite the article).

25. In addition to the sources cited in note 24, see also, among others: Timothy Donais, 'Empowerment or Imposition? Dilemmas of Local Ownership in Post-Conflict Peacebuilding Processes', Peace and Change, Vol.34, No.1, 2009, pp.12-14.

26. See especially Mac Ginty (see n.23 above); and Béatrice Pouligny, Ils Nous Avaient Promis la Paix: Opérations de l'ONU et Populations Locales, Paris: Presses de la Fondation Nationale des Sciences Politiques, 2004.

27. Schaefer (see n.24 above), pp.506-7; Simons and Zanker (see n.24 above).

28. On the need to bring the actual practice of intervention back into the debate, see Susanna Campbell, David Chandler and Meera Sabaratnam (eds), A Liberal Peace? The Problems and Practices of Peacebuilding, London: Zed Books, 2011, pp.2-3.

29. Among many others: Eyal Ben-Ari and Efrat Elron, 'Blue Helmets and White Armor: MultiNationalism and Multi-Culturalism among UN Peacekeeping Forces', City \& Society, Vol.13, No.2, 2001, pp.271-302; Tamara Duffey, 'Cultural Issues in Contemporary Peacekeeping', International Peacekeeping, Vol.7, No.1, 2000, pp.142-68; Betts Fetherston and Carolyn Nordstrom, 'Overcoming Habitus in Conflict Management: UN Peacekeeping and Warzone Ethnography', Peace and Change, Vol.20, No.1, 1995, pp.94-119; Amitav Ghosh, 'The Global Reservation: Notes toward an Ethnography of International Peacekeeping', Cultural Anthropology, Vol.9, No.3, 1994, pp.412-22; Paul Higate and Marsha Henry, Insecure Spaces: Peacekeeping in Liberia, Kosovo and Haiti, London: Zed Books, 2009, ch.7; Robert A. Rubinstein, Peacekeeping under Fire: Culture and Intervention, Boulder: Paradigm Publishers, 2008; and Sandra Whitworth, Men, Militarism and UN Peacekeeping: A Gendered Analysis, Boulder, CO: Lynne Rienner, 2004.

30. For instance, Mark Duffield, 'Risk-Management and the Fortified Aid Compound: Everyday Life in Post-Interventionary Society', Journal of Intervention and Statebuilding, Vol.4, No.5, 2010, pp.453-74; and Anne-Meike Fechter and Heather Hindman (eds), Inside the Everyday Lives of Development Workers: The Challenges and Futures of Aidland, Sterling, VA: Kumarian Press, 2011.

31. Kimberley Coles, Democratic Designs: International Intervention and Electoral Practices in Postwar Bosnia-Herzegovina, Ann Arbor: University of Michigan Press, 2007; and Anne Holohan, Networks of Democracy: Lessons from Kosovo for Afghanistan, Iraq, and Beyond, Stanford, CA: Stanford University Press, 2005.

32. Higate and Henry (see n.29 above); and Rubinstein (see n.29 above).

33. Among others: Autesserre, Peaceland (see n.1 above); and Ole Jacob Sending (ed.), Learning to Build a Sustainable Peace: Ownership and Everyday Peacebuilding, Bergen: Chr. Michelsen Institute, 2010. 
34. For instance, Kenneth Cain, Heidi Postlewait and Andrew Thomson, Emergency Sex (and Other Desperate Measures): True Stories from a War Zone, New York: Hyperion, 2004; and Robert R. Rail (ed.), Surviving the International War Zone: Security Lessons Learned and Stories from Police and Military Peacekeeping Forces, London: CRC Press, 2011.

35. Rory Stewart and Gerald Knaus, Can Intervention Work?, New York: W.W. Norton, 2012.

36. For an example of such databases, see 'Peacemakers at Risk', compiled by Sara Lindberg (at: www. pcr.uu.se/research/ucdp/program_overview/current_projects/peacemakers_at_risk/); and for an example of ethnography study across countries see Autesserre, Peaceland (see n.1 above).

37. Virginia Page Fortna, Does Peacekeeping Work? Shaping Belligerents' Choices after Civil War, Princeton, NJ: Princeton University Press, 2008, pp.2-4; and Lise Morjé Howard, UN Peacekeeping in Civil Wars, New York: Cambridge University Press, 2008, pp.2-3.

38. Florian Bieber, 'Local Institutional Engineering: A Tale of Two Cities, Mostar and Brčko', International Peacekeeping, Vol.12, No.3, 2005, pp.420-33; and Adam Moore, Peacebuilding in Practice: Local Experience in Two Bosnian Towns, Ithaca, NY: Cornell University Press, 2013.

39. Patrick Barron and Adam Burke, Supporting Peace in Aceh: Development Agencies and International Involvement, Washington, DC: East-West Center in Washington, 2008.

40. Graham Kemp and Douglas P. Fry, Keeping the Peace: Conflict Resolution and Peaceful Societies Around the World, New York: Routledge, 2004. 